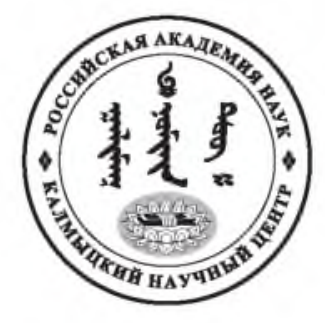

Published in the Russian Federation

Oriental Studies (Previous Name: Bulletin of the Kalmyk Institute

for Humanities of the Russian Academy of Sciences)

Has been issued as a journal since 2008

ISSN: 2619-0990; E-ISSN: 2619-1008

Vol. 14, Is. 2, pp. 226-237, 2021

Journal homepage: https://kigiran.elpub.ru

УДК / UDC 94 (517)

DOI: $10.22162 / 2619-0990-2021-54-2-226-237$

\title{
Преддоговорные основы «экспорта революции» в Восточной Азии и региональный политический порядок в зоне советского влияния: позитивный опыт и социалистическая идеология в Монголии. Год 1921. Часть 2*
}

\section{Павел Николаевич Дудин ${ }^{1}$. Зуфар Фаатович Хусаинов ${ }^{2}$}

${ }^{1}$ Восточно-Сибирский государственный университет технологий и управления (д. 40B, строение 1, ул. Ключевская, 670013 Улан-Удэ, Российская Федерация)

кандидат политических наук, директор Центра изучения государства и права стран Восточной Азии

(D) 0000-0002-9407-8436. E-mail: dudin2pavel $a$ gmail.com

${ }^{2}$ Казанский (Приволжский) федеральный университет (д. 18, Учеб́ное здание № 01 (Главный корпус университета), ул. Кремлевская, 420008 Казань, Российская Федерация) доктор юридических наук, профессор

D) 0000-0003-0388-588X. E-mail: zufar.hysainovak ksu.ru

(C) КалмНЦ РАН, 2021

(C) Дудин П. Н., Хусаинов З. Ф., 2021

Аннотация. Введение. Статья посвящена важному и содержательному периоду в истории не только двусторонних отношений между нашей страной и молодым Монгольским государством, но и становления нового регионального порядка в Восточной Азии. После крушения монархии в Китае и России во фронтирной зоне их соприкосновения образовался политический вакуум. который требовал пристального внимания и участия, чем и воспользовались Советы. Однако Соглашение об установлении дружественных отношений. заключенное в ноябре 1921 г., не следует рассматривать как некую точку отсчета, поскольку оно скорее претворяло уже имевшиеся договоренности, о которых и ведут речь авторы статьи. Исходя из этого челью настояией ста$m$ ви является на основе междисциплинарного подхода выявить роль и значение тех документов (обращений, нот, писем и др.), которые до заключения Соглашения между РСФСР и Монголией об установлении дружественных отношений от 5 ноября 1921 г. определяли и формализовали

* Первая часть статьи опубликована: Дудин П. Н.. Хусаинов 3. Ф. Преддоговорные основы «экспорта революции» в Восточной Азии и региональный политический порядок в зоне советского влияния: позитивный опыт и социалистическая идеология в Монголии. Год 1921. Часть 1 // Oriental Studies. 2021. T. 14. № 1. C. 8-23. DOI: 10.22162/2619-0990-2021-53-1-8-23 
внешнюю политику Советской России в регионе и обеспечивали ее присутствие на территории Внешней Монголии. Материальл и методы. В своей работе авторы опираются на материалы, хоть и известные широкой научной общественности посредством их публикации в различного рода сборниках советской эпохи, однако не рассматриваемые большинством исследователей в качестве важного инструмента обеспечения советских интересов на Дальнем Востоке. Таким образом, научная новизна выражается в представлении результатов изучения обращений, нот и писем сквозь призму знаний других гуманитарных наук - юриспруденции и политологии. В свою очередь данная позиция предопределила междисциплинарный характер настоящей статьи с опорой на исторические, юридические и политологические методы, а также с использованием дефиниций и категорий, применяемых в области международного права и международных отношений. С целью обеспечения более комфортного восприятия материала специалистами разных направлений он был разделен на две части. В первой части авторы сконцентрировали внимание на инструментарии исследования и его идеологической составляющей, а во второй части, которую и представляет настоящая статья, — на конкретных инструментах обеспечения «экспорта революции». Bыводы. Поскольку исследовательское внимание уделено письмам и обращениям советской и монгольской стороны, а также другим документам, именуемым преддоговорными и раскрывающим истинный смысл и идеологическую подоплеку обновленных взаимоотношений, авторы заявляют о выделении нескольких ключевых направлений для сотрудничества, наиболее важным из которых в предыдущей части работы было обозначено двухстороннее взаимодействие. В настоящей статье будет дана характеристика других направлений, которые можно обозначить и как набор действенных инструментов по закреплению идеологической основы «экспорта революции». Среди них: «мягкая сила» в виде образовательных проектов; обеспечение безопасности советской территории и советских границ, предполагающее оказание помощи монгольским товарищам в борьбе с белогвардейцами, сохранение частей Красной Армии на монгольской территории до окончательной ликвидации белогвардейской угрозы с привлечением к этому процессу военных соединений Дальневосточной республики; экономическое сотрудничество, выражавшееся в финансовой и экономической помощи при строительстве заводов и комбинатов, разработке месторождений полезньх ископаемых и создании социальной инфраструктуры и т. п.; совместные действия на международной арене, апофеозом которых стало международное признание Монгольской народной республики как со стороны Китая (1946 г.), так и остального мирового сообщества (1961г.). В ходе проведенного исследования авторы приходят к выводу о том, что все эти направления были реализованы в течение последующих двух десятков лет и сыграли определяющую роль не только в формировании нового политического порядка в регионе, но и при выстраивании системы безопасности восточных рубежей нашей страны в предвоенный и военный период (1936-1945 гг.), что не позволило Японии развязать войну на Дальнем Востоке с участием СССР вплоть до 1945 г. и обеспечило безопасность Монгольской народной республики.

Ключевые слова: внешняя политика, стратегическое присутствие, Монголия, международный договор, соглашение, признание правительства, обращение, региональный политический порядок, Восточная Азия, социалистическая идеология

Благодарность. Исследование выполнено при финансовой поддержке РФФИ в рамках научного проекта № 19-09-00502 «Институты российского / советского стратегического присутствия в Восточной Азии в ХХ в.».

Для цитирования: Дудин П. Н., Хусаинов 3. Ф. Преддоговорные основы «экспорта революции» в Восточной Азии и региональный политический порядок в зоне советского влияния: позитивный опыт и социалистическая идеология в Монголии. Год 1921. Часть 2 // Oriental Studies. 2021.T. 14. № 2. C. 226-237. DOI: 10.22162/2619-0990-2021-54-2-226-237

\title{
Precontractual Essentials for the 'Export of Revolution' in East Asia and Regional Political Order in the Zone of Soviet Influence: Positive Experience and Socialist Ideology in Mongolia. The Year 1921. Part 2
}

\author{
Pavel N. Dudin ${ }^{1}$, Zufar F. Khusainov ${ }^{2}$
}


${ }^{1}$ East Siberia State University of Technology and Management (40B/1, Klyuchevskaya St., 1670013 Ulan-Ude, Russian Federation)

Cand. Sc. (Political Science), Director of the Center for the Study of State and Law of East Asian Countries

0000-0002-9407-8436. E-mail: dudin2pavel@gmail.com

${ }^{2}$ Kazan Federal University (18, Bldg. 01, Kremlyovskaya St., 420008 Kazan, Russian Federation)

Dr. Sc. (Law). Professor

0000-0003-0388-588X. E-mail: zufar.hysainov@ ksu.ru

(C) KalmSC RAS, 2021

C Dudin P. N., Khusainov Z. F., 2021

Abstract. Introduction. The article deals with an important and eventful period of Russia-Mongolia relations, special attention be paid to the shaping of a new regional order in East Asia. The collapse of China's monarchy resulted in a political vacuum in Russia's border territories which required utmost consideration and involvement, and the Soviets did seize the opportunity. However, the Agreement on Friendly Relations concluded in November of 1921 can hardly be viewed as a starting point, the former having been rather supposed to actualize previous mutual commitments discussed in the paper. Goals. So, the work attempts an interdisciplinary insight into the mentioned documents (addresses, diplomatic notes, letters, etc.) to have preceded the Agreement and formalized Soviet Russia's foreign policy in the region and its presence in the territory of Outer Mongolia - to determine the role and impact of those preliminary papers. Materials and Methods. The study focuses on widely known materials contained in diverse published collections of documents from the Soviet era that were never viewed by most researchers as important tools to have guaranteed the national interests in the Far East. So, the innovative aspect of research is that the addresses, notes and letters are examined through the prism of other humanitarian disciplines, such as jurisprudence and political science - to result in the employment of an interdisciplinary approach with a range of historical, juridical and politological research methods, definitions and categories inherent to international law and international relations. Part One of the article focuses on research tools and ideological essentials, while Part Two examines the actual techniques to have secured the 'export of revolution'. Conclusions. The insight into the precontractual documents has delineated a number of key lines for cooperation, the latter dominated by bilateral collaboration (and described in Part One). This paper shall characterize the rest that can be together identified as a set of efficient means to have consolidated ideological foundations of the 'export of revolution' that include as follows: 'soft power' of educational projects; security arrangements for Soviet territories and borders, including assistance to Mongolian comrades in their fight against the White Guard, allocation of the Red Army units within Mongolian territories until the complete eradication of the White threat, with the participation of military units from the Far Eastern Republic; economic cooperation through mutual financial and economic support of industrial construction projects, resource development and social infrastructure initiatives, etc.; joint actions on the international stage pinnacled with the recognition of the Mongolian People's Republic by China (1946) and the rest of the world community (1961). The study concludes these lines of cooperation were successfully implemented within the two following decades and proved crucial not only in the shaping of a new political order in the region but also facilitated the development of the eastern border security system in the pre-war period and WWII proper (1936-1945), which restrained Japan from initiating military actions against the USSR up until 1945 and guaranteed the security of Mongolia.

Keywords: foreign policy, strategic presence, Mongolia, international treaty, agreement, government recognition, appeal, regional political order, East Asia, Socialist ideology

Acknowledgements. The reported study was funded by RFBR, project no. 19-09-00502 'Institutions of Russian / Soviet Strategic Presence in East Asia: 20 ${ }^{\text {th }}$ Century'.

For citation: Dudin P. N., Khusainov Z. F. Precontractual Essentials for the 'Export of Revolution' in East Asia and Regional Political Order in the Zone of Soviet Influence: Positive Experience and Socialist Ideology in Mongolia. The Year 1921. Part 2. Oriental Studies. 2021. Vol. 14(1): 226-237. (In Russ.). DOI: 10.22162/2619-0990-2021-54-2-226-237 


\section{Введение}

2021 г. для специалистов в области международных отношений в Восточной Азии и экспертов в сфере национальной безопасности в этой части Азиатского континента предполагает знаковое юбилейное событие: 100 лет установления дипломатических отношений между нашей страной и Монголией. Однако, несмотря на то, что Соглашения об установлении дружественных отношений между Россией и Монголией от 5 ноября 1921 г. считается крупнейшей победой советской дипломатии на Востоке на раннем этапе формирования советской государственности, сам 1921 г. наполнен не менее яркими событиями и актами, нотами и обращениями, заслуживающими особого научного внимания, чему и посвящена настоящая статья.

Актуальность заявленного исследования обусловлена рядом факторов на высшем уровне государственной власти нашей страны, о которых мы вели речь в первой части нашей работы [Дудин 2021]. В связи с этим интересен опыт их выстраивания, когда оба государства, устоявшиеся во взаимных отношениях с момента провозглашения независимости Монголии в 1911 г., перешли на новый этап своего государственного развития: наша страна встала на рельсы социалистических идей, а Монголия, во второй раз избавившись от попыток подчинения со стороны Китая, только выбирала путь своего развития.

\section{Материалы и методы}

Методологическая основа исследования описана в первой части нашей работы и обусловлена ее междисциплинарным характером при доминирующем присутствии исторического научного знания, подразделена на общенаучные, исторические, политологические и юридические методы, подходы и принципы. Среди исторических методов, принципов и подходов мы опирались на проблемно-хронологический подход, описательно-повествовательный метод, нарративный подход, принцип историзма, историко-системный, ретроспективный, а также использовали внешнюю и внутреннюю критику источников как методологический прием и их текстологический анализ. Среди политологических и правовых методов, подходов и категорий применялись кроссисторические сравнения, поведенческий подход, сбор данных, тематический мониторинг источников и дискурс-анализ, а также категория международных лиц в качестве субъектов международного права и участников международных отношений, понятие государства и отдельные позиции относительно теории международного признания.

Основу источниковой базы и исследовательского материала составили письма, обращения и ноты, направляемые друг другу советской и монгольской стороной, содержащиеся в соответствующих сборниках советской эпохи, междисциплинарный подход в работе с которыми позволил рассмотреть их в ракурсе категории регионального политического порядка и советского стратегического присутствия.

Региональный политический порядок в пространстве специальных российских / советских интересов в Восточной Азии (в преддверии заключения Соглашения между РСФСР и Монголией об установлении дружественных отношений)

Современное монголоведение - в трудах российских и монгольских учен ых

В предыдущей части мы указывали на наиболее авторитетных ученых, которые в своих трудах исследуют двусторонние российско-монгольские отношения. К их числу следует, в первую очередь, отнести Б. В. Базарова, Е. А. Белова, В.В.Грайворонского, Ю. В. Кузьмина, С. Г. Лузянина, а также тех отечественных исследователей, которые акцентируют внимание на предметных областях нашего сотрудничества: А. В. Михалева и его работы как относительно историографии Монгольской революции 1921 г. [Михалев 2005], так и в ракурсе российской и советской дальневосточной политики [Михалев 2017] и институтов политического присутствия [Михалев 2019]; Л. В. Кураса [Курас 2015] и С. Л. Кузьмина [Кузьмин 2015a] и их трудов в области проблем пан-монголизма и монгольской государственности и др. Среди монгольских 
ученых значительный интерес представляют труды ученого и дипломата Ж. Баясаха относительно стратегического партнерства между нашими странами [Баясах 2017], а также других исследователей, к работам которых мы апеллировали и апеллируем в нашем исследовании.

“Дальневосточный вектор》 внешней политики Советской России и его монгольское преломление: идеологические контуры

В предыдущей статье мы отмечали, что с крушением Российской империи Советы не спешили признавать себя преемниками предыдущей власти. Более того, они заняли решительную позицию отмежевания как от прежних подходов в реализации внешней политики на Дальнем Востоке, так и от договоров и обязательств, ей порожденных. Однако, несмотря на столь широкий жест, целью которого была публичная демонстрация добрососедских намерений, политические реалии требовали бдительной внешней политики и обеспечения безопасности восточных рубежей государственной границы, тем более что за ней сумел создать себе плацдарм главнейший враг молодого социалистического государства - барон Роман Федорович Унгерн. В результате революционная эйфория не помешала добиться желаемого порядка в регионе, и сделать это стало возможно без официальных церемоний, переговоров и подписания витиеватых документов. Взаимодействие на описываемом же этапе предполагалось по нескольким направлениям. Первое (I) среди них - это двухстороннее взаимодействие, включающее в себя «экспорт идеологии» и соответствующие инструменты его обеспечения, а именно 1) отмежевание от прежнего режима: «прежнее царское правительство», (〈царский режим» и т. д.; 2) поддержка антиколониальных (в первую очередь антикитайских) настроений; 3) равноправие во внешнеполитических вопросах; и 4) совместная борьба в отношении общих врагов.

Инструментарий стратегического присутствия Советской России в регионе: практическое воплоцение

В качестве второго (II) направления следует определить планомерную, поступательную и эффективную политику по привлечению на свою сторону жителей подконтрольных буферных государств посредством образования и просвещения, или то, что сейчас называется (Мягкой силой», где можно обозначить два вектора: а) работа посредством «экспорта знаний» через преподавательские кадры; и б) работа посредством (ииморта молодых умов» через обучение в советских учебных заведениях монгольской молодежи. Рассмотрим эти аспекты более детально.

По условиям Советско-китайского соглашения 1924 г. и декларации к нему оговаривалось: «Русская доля боксерского возмещения, от которой Правительство Союза Советских Социалистических Республик... будет, после удовлетворения всех прежних обязательств, направлена исключительно и полностью на создание фонда улучшения просвещения китайского народа) [Сборник действующих договоров 1935: 54], 一 и далее шло разъяснение о порядке его образования, управления и т. д.

В Монголии 8 марта 1922 г. Народным правительством было принято решение с целью улучшения работы школ поручить министерству внутренних дел пригласить из Советской России двух педагогов-консультантов, хорошо знающих монгольский язык [Советско-монгольские отношения 1975 73], что и было сделано. Вслед за письмом от 6 декабря 1923 г. Центрального Комитета Монгольского революционного союза молодежи было принято решение направить «10 преданных делу революции, талантливых молодых людей на учебу в Институт Востока в Москве», что предполагало «содействие воспитанию и обучению молодого поколения партии и народа» [Советско-монгольские отношения 1975: 88-89], а спустя год Комитетом по заведованию ученой, учебной и литературно-издательской частью учреждений ЦИК СССР правлению Ленинградского института живых восточных языков имени А. С. Енукидзе было дано распоряжение о приеме на рабочий факультет 15 монгольских студентов [Советско-монгольские отношения 1975: 133]. Этим была заложена прочная традиция приглашения советских научных и образовательных работников в Монголию и обратный процесс, когда монгольские обучающиеся приезжали для этой цели в Советский Союз, перенесенная позднее на другие социалистические государства и режимы. 
Ситуация в сфере начального образования была крайне тяжелая, о чем можно судить из переписки монгольского педагога Д. Эрдэни-Батухана [Советско-монгольские отношения 1975: 107-111], направленного для изучения немецкого опыта в СССР и Германию, и А. М. Горького [Советско-монгольские отношения 1975: $113-$ 114]. Распространение образования в Монголии, по мнению Д. Эрдэни-Батухана, усложнялось кочевым образом монгольской жизни и тем, что основными культурными и образовательными центрами долгое время были (и продолжали оставаться на момент написания письма) монастыри, а ламы ключевыми носителями знаний, констатируя, что $40 \%$ мужского населения получали воспитание в низших, средних и высших буддийских школах. И, несмотря на многие таланты, которыми обладало духовенство, в настоящее время оно находилось в упадке, равно как и система образования, где материальное победило духовное, по меткому замечанию Д. Эрдэни-Батухана: «...духовенство в массе своей превратилось давно в мирян, которым ничто человеческое не чуждо. Они не прочь ,защищать“ материальные интересы своей касты в ущерб интересам народа и тянутся к власти над народом, привыкшим им верить и окружать их ореолом носителей заветов высоких буддийских принципов》 [Советско-монгольские отношения 1975: 108]. Таким образом, здесь буддийская философия имела определяющее значение.

По мнению Д. Эрдэни-Батухана, для закрепления и углубления реформ, подвигнутых «Народной революцией», недостаточно мероприятий политико-экономического характера, нужно «направить по надлежащему руслу» «народное сознание и воспитание подрастающего поколения, а для этого государство должно было изъять из рук клерикалов могучее орудие - школу и взять ее в свое исключительное ведение. Школа должна быть светская, и в ней подрастающее поколение и даже взрослые будут обучаться точным знаниям, являющимся основой современной материальной и духовной культуры» [Советско-монгольские отношения 1975: 109]. При этом он признавал, что объективные условия по закрытию всех буддийских школ на данный момент отсутствуют. Он подчеркивал, что светская школа должна отвечать требованиям, «предъявляемым к ней духом времени, жизнью, и современным педагогическим и методическим положениям и этим в глазах населения стояла бы на голову выше старых школ》 [Советско-монгольские отношения 1975: 110].

Для молодежи это обстоятельство будет служить бесспорным аргументом в пользу и светского обучения. Для того чтобы выстроенная образовательная система была эффективной, Монголии необходимо было, по мнению педагога, обратиться к опыту советской школы, равно как и к опыту «других народов, достигших высокой степени развития наук и искусств» [Советско-монгольские отношения 1975: 110].

В качестве примера по возрождению древних познаний в языке и культуре Д. Эрдэни-Батухан приводил Бурят-Монгольскую Автономную Советскую Социалистическую Республику (БМАССР): «Зарубежные монголы с глубоким интересом следят, как их сородичи бурят-монголы, входящие в состав Союза советских республик, до революции в большинстве своем забывшие свою грамоту вследствие русификации и почти предавшие забвению свою литературу, теперь свободно учатся на своем языке. Развивается у них пока что учебная литература в связи с национализацией школ. Молодежь со свойственным ей энтузиазмом ведет политико-просветительную работу и попутно закладывает основу бурят-монгольского театра. Пишутся пьесы, которые с успехом ставятся в народных театрах》 [Советско-монгольские отношения 1975: 110].

В ответном письме Д. Эрдэни-Батухану А. М. Горький ратует за активную гражданскую позицию: «... именно активному отношению к жизни Европа обязана всем тем, что в ней прекрасно и достойно уважения всеми расами. „Желание - суть источник страдания", - учил Будда. Европа ушла вперед других народов мира в области науки искусства и техники именно потому, что она никогда не боялась страдать, всегда желая лучшего, чем то, чем она уже обладает. Она сумела пробудить в массах своего народа стремление к справедливости, к свободе, и за одно это мы должны простить ей множество ее грехов и преступлений. Мне кажется, что, знакомя монгольский народ с 
духом Европы и современными нам желаниями ее масс... Вам следует переводить именно те европейские книги, в которых наиболее ярко выражен принцип активности, напряжения мысли, стремящейся к деятельной свободе, а не к свободе бездействия) [Советско-монгольские отношения 1975: 114].

И уже 26 августа 1925 г. Правительство БМАССР приняло решение о предоставлении пяти мест для обучения монгольских граждан в своей партийной школе, где «обучение для бурят и монголов будет вестись на монгольском языке. Срок обучения в советско-партийной школе один год. Окончившие школу могут быть работниками худонов в качестве пропагандистов идей и мероприятий своего правительства и по поднятию культурного уровня монгольского трудового народа. Обучение, содержание проводится за счет нашей республики...» [Советско-монгольские отношения 1975: 116]. Об этом в письме правительству МНР сообщает Председатель ЦИК и СНК Бурят-Монгольской АССР М. Ербанов. Развивая тезис В. И. Ленина о «пробуждающейся Азии», автор письма подчеркивает, что культурно-национальное пробуждение малых народностей ведет к безболезненному единению «их с другими через красивое разнообразие форм единого содержания» [Советско-монгольские отношения 1975: 110]. «Вообше пробуждение восточных народов в 20-м веке, когда в странах Запада поговаривают о переоценке ценностей, очень интересно. Теперь только начало этого пробуждения, и как быстро оно пойдет вперед, что для этого нужно, составляет для нас проблему (методическую)» [Советско-монгольские отношения 1975: 111]. Очень верное и своевременное замечание, актуальное и сегодня. Складывающаяся система советско-монгольских отношений была удобна и советской, и монгольской стороне: монголы получали кадры для развития и укрепления одной из важнейших сфер общественной жизни, а СССР - еще один инструмент укрепления своего влияния в контролируемом буферном государстве.

Третье (III) направление взаимодействия предполагало также обеспечение безопасности советской территории и советских границ и - как следствие - территории и границ партнеров. Первым актом официального военного присутствия Советской России в регионе стало решение об оказании помощи монгольским товарищам в борьбе с белогвардейцами. Оно явилось ответом на обращение монгольской стороны от 16 марта 1921 г. за военной помощью против вооруженных отрядов Унгерна, Шмакова, Комаровского, Сухарева и др. Эксплуатируя образ убийц и грабителей («производя неслыханные насилия, отбирая у мирного населения лошадей, скот и имущество, производят убийства и грабежи как среди монголов, так и среди русских и китайцев»), использовались и более весомые аргументы, как-то угроза национальным интересам России («вмешиваются в дела управления Монголии, пытаясь направить монгольский народ против великой РСФСР и сделать его слепым орудием в руках чужеземных насильников») [Советско-монгольские отношения 1975: 8].

Аргументируя свою просьбу тем, что белогвардейцы одинаково угрожают мирному населению как Монголии, так и России, Временное Народное правительство Монголии обращалось к Правительству РСФСР с просьбой о предоставлении военной помощи [Советско-монгольские отношения 1975: 7-8], что было особенно актуально, поскольку в этот период времени широко распространялась информация о японском участии в освещаемых процессах [Кузьмин и др. 2009].

Японцы, известные своей жестокостью, уже успели оставить о себе худую память у жителей Читы и Верхнеудинска. В связи с чем подобного рода сообщения вызывали бурную реакцию среди населения. Так, 31 марта 1921 г. в иркутской газете «Власть труда» была помещена заметка от интервью барона Унгерна иностранным корреспондентам, в котором он заявил, что «ноябрьские операции против Урги были предприняты с ведома и поддержки японцев. По мнению пекинских газет, планы Семенова в Монголии совпадают со стремлениями японцев образовать буфер из Маньчжурии и Монголии, а также планами Чжан Цзолиня восстановить Маньчжурскую династию. В Урге состоялось совещание японских, белогвардейских, монгольских командиров под председательством хутухты, между прочим, обсуждалось предложение Семенова направить силы в Читу. Монгольские 
белогвардейцы подготовляют захват Хайларского района посылкой туда войск. Прибывшие из Урги иностранцы сообщают о расстрелах Унгерном коммунистов, евреев и военнопленных немцев) [Советско-монгольские отношения 1975: 8-9].

В целом события и процессы, описанные в заметке, имеют соответствующую подоплеку. Так, известно, что Богдо-хан симпатизировал Унгерну, равно как известно о попытке Г. М. Семенова в 1919 г. организовать «Великое Монгольское государство» [Курас 2011; Курас 2014], для чего в Хайларе и Чите были проведены съезды монгольской знати, военных и прочих неравнодушных к этим идеям. Известны также планы японцев по выстраиванию буферной государственности на монгольско-маньчжурской территории и о дискуссиях с участием японских и китайских военных о восстановлении династии Цин [Дмитриев, Кузьмин 2020], которым суждено было воплотиться, правда, в иной форме и на ином географическом пространстве.

Эти же события отслеживало командование Народно-революционной армии Дальневосточной республики - другого буферного государства. Так, в сводках от 3 апреля 1921 г. [Советско-монгольские отношения 1975: 10] и 1 мая 1921 г. [Советско-монгольские отношения 1975: 11] сообщалось об успехе поднятого монголами восстания и взятии ими ряда ключевых населенных пунктов, образовании революционного правительства, в числе задач которого - тесное сотрудничество с Советской Россией и ДВР, а также со ссылкой на зарубежную прессу сообщалось о волнениях в Западной Монголии и занятии белогвардейцами Кобдо и Уланкома. В этих же сводках сообщалось о тесной связи атамана Анненкова с бароном Унгерном и Богдо-гэгэном, что ставило последнего в один ряд с предателями народных интересов, противопоставляя его позицию позиции других монгольских аристократов: в частности, сообщалось, что князь Ахайгун перешел на сторону «красномонголов» и объявил мобилизацию своего хошуна. Таким образом, Советы получали оперативную информацию и имели возможность своевременного на нее реагирования не только посредством собственных ресурсов, но и через создаваемые ими буферные структуры. В дальнейшем такой механизм будет использован при попытке «экспорта революции» в Китай, однако окажется менее успешным, в силу как объективных, так и субъективных характеристик.

12 июля 1921 г. «Народное революционное правительство) Монголии обратилось к Правительству РСФСР с просьбой не выводить части Красной Армии с территории Монголии до момента окончательной ликвидации угрозы «со стороны обшего врага, в настоящее время укрепившегося в восточных степях》 [Советско-монгольские отношения 1975: 28]. Обращение было вынужденной акцией, «потому, что Монгольское Правительство еще не закончило организации аппарата новой власти. Оставление советских войск диктуется обстоятельствами в целях сохранения безопасности на Территории Монголии и на границах РСФСР») [Документы 1960: 259].

10 августа 1921 г. советское руководство в лице народного комиссара по иностранным делам РСФСР Г. В. Чичерина ответило согласием на просьбу монгольской стороны [Советско-монгольские отношения 1975: 35-37], однако ответ интересен не этим, а рядом весьма любопытных моментов. Во-первых, он давался от лица не только РСФСР, но и союзного Правительства «братской» Дальневосточной Республики. Во-вторых, Монголия называлась автономной, таким образом, советское руководство не торопилось признавать страну независимой, речь шла лишь о «создании нового свободного строя) [Советско-монгольские отношения 1975: 36], а не государства с точки зрения его государственного суверенитета. В-третьих, направлением взаимодействия предполагалось «вступление советских войск на территорию автономной Монголии», целью которого было «сокрушение общего врага, устранение постоянной опасности, угрожающей советской территории, и обеспечение свободного развития и самоопределения автономной Монголии) [Советско-монгольские отношения 1975: 36]. Однако после окончательного устранения угрозы свободному развитию монгольского народа и безопасности Российской Республики и Дальневосточной Республики войска РККА по просьбе правительства Монголии должны были оставаться на ее территории вплоть до 1926 г. 
26 ноября 1924 г. была провозглашена Монгольская народная республика и принята первая Конституция нового государства [Дурденевский, Лудшувейт 1926: 157]. И только после этого, после формирования новых органов государственной власти и окончательного укоренения социалистической идеологии среди нового руководства страны, устранения угрозы со стороны Японии и присоединения к РСФСР одного из буферных государств региона, Дальневосточной Республики, руководство РСФСР посчитало возможным осуществить вывод своих войск с территории другого государства, по-прежнему признавая за ним автономный статус в составе Китайской Республики. 24 января 1925 г. нотой правительства СССР председатель Совета Министров МНР Б. Цэрэндорж был уведомлен о выводе советских войск с монгольской территории. «Правительство СССР считает, что пребывание советских войск в пределах Монгольской Народной Республики уже не вызывается необходимостью) [Советско-монгольские отношения 1975: 103 104]. Нота воспроизводила причины и условия сохранения советского присутствия на территории буферного автономного государства, а его длительность обосновывалась необходимостью защиты монгольских и советских военных частей, установления «действительного порядка» и «обеспечения условий для дальнейшей демократизации страны〉 [Советско-монгольские отношения 1975: 104]. При этом СССР объявлялся правопреемником РСФСР в вопросе «ведения внешних сношений Российской Республики〉 [Советско-монгольские отношения 1975: 103-104]. Формировалась новая система национальной безопасности на основе созданного регионального политического порядка. Эта система показала свою эффективность после вторжения японских войск на территорию Маньчжурии, создания Маньчжоу-Го и попыток проверить ее на прочность событиями на р. Хасан и оз. Халхин-Гол в 1938-1939 гг. Несмотря на неоднозначный международно-правовой статус МНР [Кузьмин 2015б], обстановка, тем не менее, требовала от СССР признания суверенитета Китая над Монголией, в связи с чем 10 марта 1925 г. советский посол уведомил руководство в Пекине о завершении вывода частей Красной Армии из Внешней
Монголии [Внешняя политика 1945, III: 13]. Нота была составлена без идеологического флера и оставляла китайскому правительству надежду «разрешить путем мирного соглашения с монгольским народом вопрос о взаимоотношениях между двумя братскими народами» [Советско-монгольские отношения 1975: 531].

Четвертым (IV) направлением советско-монгольского взаимодействия предполагалось, безусловно, экономическое сотрудничество: именно наша страна была основным источником финансовой и экономической помощи при строительстве заводов и комбинатов, разработке месторождений полезных ископаемых и создании социальной инфраструктуры, но и Монголия оказывала помощь нашей стране. В 1921 г. заместитель полпреда РСФСР в Монголии А. Я. Охтин (1921-1922) благодарил премьер-министра Монголии Д. Бодоза то, что правительство монгольской стороны «широко пошло навстречу смягчения великого бедствия Русского Советского государства и пожертвовало тысячу ... голов скота, а также издало обращение ко всему монгольскому народу, призывающее помочь дружественному народу Советроссии, жертвуя в пользу голодающих кто что может» [Советско-монгольские отношения 1975: 55-56]. Для современных российско-монгольских взаимоотношений это имеет ключевое значение.

И, наконец, пятое (V) направление: совместные действия на международной арене, борьба за укрепление мирового коммунистического рабочего движения. События 1920-х гг. в регионе и активное участие в них советской стороны имели важное идеологическое значение: отныне в основе заключаемых союзов советского и монгольского или советского и китайского народов лежала не только общность интересов трудящихся, но и человеческие потери в ходе совместной революционной борьбы.

В октябре 1921 г. в Москву прибыла чрезвычайная монгольская миссия. 5 ноября 1921 г. ее глава, основатель МНРП и Монгольского народного государства Д. Сухэ-Батор, был принят В. И. Лениным в Кремле [Советско-монгольские отношения 1975: VI]. На встрече вождь советского народа заявил, что «единственно правильным путем для всякого трудящегося вашей 
страны является борьба за государственную и хозяйственную независимость в союзе с рабочими и крестьянами Советской России. Эту борьбу изолированно вести нельзя, поэтому создание партии монгольских аратов является условием успешности их борьбы» [Советско-монгольские отношения 1975 : 56-57].

В ходе беседы [Ленин 1970: 232-233] было отмечено особое географическое положение Монголии и стремление других стран захватить МНP и превратить ее в плацдарм борьбы против Советской России. Исходя из этой вполне реальной на тот момент угрозы, советское руководство включило Монголию в сферу своих политических и идеологических интересов. Данная установка определила политическое развитие Монголии на ближайшие два десятка лет и стала определяющим инструментом в политической борьбе конца 1920 г. - первой половины 1930-х гг. в стране.

В тот же день между Народным Правительством Монголии с одной стороны и Правительством Российской Социалистической Федеративной Советской Республики с другой было заключено Соглашение об установлении дружественных отношений между Монголией и Россией. Обе стороны заявляли о взаимном признании, обязывались не допускать актов, враждебных друг другу, и согласились применять принцип наибольшего благоприятствования в политических и экономических взаимоотношениях. Как советская, так и современная историческая наука и ее представители считают, что документ стал реальным шагом выхода Монголии из политической изоляции, что позволило молодому Монгольскому государству после окончания Второй мировой войны стать полноправным субъектом международного права.

\section{Заключение}

В современных условиях созданная модель взаимоотношений, не являющаяся идеальной и справедливой, по мнению ряда исследователей, тем не менее доказала свою эффективность. Точно также доказала свою эффективность и внешняя политика нашей страны, не всегда однозначно оцениваемая и одобряемая современниками. Так, несмотря на поражение в Русско-японской войне, Портсмутский мирный договор позволил
России сохранить свое присутствие в регионе и заключить с Японией в 1907-1916 гг. четыре Соглашения о разделе сфер влияния, благодаря чему наша страна смогла гарантировать безопасность своих интересов, территорий и границ: следующий военный конфликт с Японией состоялся лишь в августе 1945 г. Аналогичным образом выстраивались отношения с монгольской стороной: взвешенные, с учетом интересов контрагента и тех реалий, которые имели место быть на международной арене.

Политический вакуум, образовавшийся после крушения монархии в Китае и России во фронтирной зоне их соприкосновения, требовал пристального внимания и участия, чем и воспользовались Советы. При этом, вопреки расхожему в научной литературе мнению, Соглашение об установлении дружественных отношений между правительствами РСФСР и Внешней Монголии, заключенное в ноябре 1921 г., мы не склонны рассматривать как отправную точку в официальных двусторонних отношениях, поскольку этому уже предшествовала череда переговоров и договоренностей. Многие исследователи называли и называют это Сoглашение первым равноправным договором в истории Монголии, равно как и фундаментом дальнейшего развития взаимоотношений Советской России и Монголии. Этой позиции сложно возразить: по нашему мнению, оно оформляло и закрепляло наиболее важные аспекты двустороннего сотрудничества, которое, тем не менее, этими положениями не исчерпывалось. Важное значение имели письма и обращения советской и монгольской стороны, а также другие документы, именуемые нами как преддоговорные, поскольку именно в них и раскрывался истинный смысл и идеологическая подоплека обновленных взаимоотношений и именно они, в первую очередь, создали необходимые условия при выстраивании системы безопасности восточных рубежей нашей страны в предвоенный и военный период (1936-1945 г.), что не позволило Японии развязать войну на Дальнем Востоке с участием СССР вплоть до 1945 г. и обеспечило безопасность МНР. И в современных условиях, когда многие исторические события и факты подвергаются пересмотру и переоценке, и для российской, и для монгольской сторон важно знать не только о 
ключевых событиях в истории Восточной Азии, таких как события на о3. Хасан или на р. Халхин-Гол, но и о скрытых от широких

\section{Литература}

Баясах 2017 - Баясах $Ж$. Новое развитие отношений между Монголией и соседними странами // Eurasia: statum et legem. 2017. № 8. C. 6-12.

Внешняя политика 1945, III - Внешняя политика СССР: Сб. док. Т. III: (1925-1934 гг.) / Высшая партийная школа при ЦК ВКП(б). Кабинет социально-экономических наук; сост. науч. сотр. Кабинета социально-экономических наук ВПШ при ЦК ВКП(б) А. С. Тисминец. М.: ВПШ при ЦК ВКП(б), $1945.800 \mathrm{c}$.

Дмитриев, Кузьмин 2020 - Дмитриев С. В., Кузьмин С. Л. Движение за восстановление монархии после Синьхайской революции (по данным российских архивов). Реставрация цинской монархии Чжан Сюнем // Восток. Афро-азиатские общества: история и современность. 2020. Вып. 4. С. 180-195.

Документы 1960 - Документы внешней политики СССР. Т. 4: 19 марта 1921 г. - 31 декабря 1921 г. / Министерство иностранных дел СССР. М.: Госполитиздат, 1960. 836 с.

Дудин 2021 - Дудин П. Н. Преддоговорные основы «экспорта революции» в Восточной Азии и региональный политический порядок в зоне советского влияния: позитивный опыт и социалистическая идеология в Монголии. Год 1921. Часть $1 / /$ Oriental Studies. 2021. T. 14. № 1. C. 8-23. DOI: $10.22162 / 2619$ 0990-2021-53-1-8-23

Дурденевский, Лудшувейт 1926 - Дурденевский B. Н., Лудиувейт Е. Ф. Конституции Востока. Л.: Госиздат, 1926. 180 с.

Кузьмин 2015а - Кузьлин С. Л. Панмонгольское движение 1919-1920 гг. и монгольская государственность // Eurasia: statum et legem. 2015. № 1 (4). C. 97-107.

Кузьмин $20156-$ Кузьмин С. Л. Советско-китайские отношения и проблема статуса Монголии в 1920-х годах // Россия и Монголия в первой половине XX века: концептуальные вопросы российско-монгольских отношений (дипломатия, экономика, наука). Иркутск: Изд-во БГУ, 2015. С. 247-255.

Кузьмин и др. 2009 - Кузьмин С. Л., Батсайхан О., Нунами К., Тачибана $M$ Барон Унгерн и Япония // Восток. Афро-Азиатские общества: история и современность. 2009. № 5. C. 115-133. масс процессах, определявших региональный политический порядок в первой половине XX в.

Курас $2011-$ Курас Л. В. Геополитические амбиции атамана Семенова: попытка создания федеративного «Велико-монгольского государства» // Гуманитарный вектор. 2011. № 4 (28). C. 255-262.

Курас 2014 - Курас Л. В. «Три жизни» атамана Г. М. Семенова: любовь и предательство (к вопросу о фронтире) // Известия Иркутского государственного университета. Сер.: История. 2014. Т. 7. С. 94-113.

Курас 2015 - Курас Л. В. «Великое Монгольское государство» атамана Семенова: государство, которого не было // Eurasia: statum et legem. 2015. № 1 (4). С. 84-96.

Ленин 1970 - Ленин В. И. Беседа с делегацией Монгольской Народной Республики, 5 ноября 1921 года. Полн. собр. соч. Т. 44. М.: Политиздат, $1970.725 \mathrm{c}$.

Михалев 2005 - Михалев A. В. Монгольская революция 1921 года в советской и российской историографии: дисс. ... канд. ист. наук. Улан-Удэ, 2005. 154 с.

Михалев 2017 - Михалев A. В. Постжелтороссия, или Русские колонисты в социалистической Монголии // Вестник Бурятского научного центра Сибирского отделения Российской академии наук. 2017. № 4 (28). С. 80-88.

Михалев 2019 - Михалев А. В. «Прогрессоры степей» или советские специалисты в Монголии: историческая память об́ одном политическом проекте // Восточные ветви российской диаспоры в прошлом и настоящем (коллективная монография). М.: ИВ РАН, 2019. C. 15-34.

Сборник действующих договоров 1935 - Сборник действующих договоров, соглашений и конвенций, заключенных с иностранными государствами. Вып. I-II: Действующие договоры, соглашения и конвенции, вступившие в силу до 1 января 1925 года / СССР. Народный Комиссариат по Иностранным Делам; под ред.: А. В. Сабанин, В. О. Броун. 3-е изд., испр. и доп. М.: Изд-е НКИД, 1935. $484 \mathrm{c}$.

Советско-монгольские отношения 1975 - Coветско-монгольские отношения 1921-1974: Док. и мат-лы: в 2 т. Т. 1: 1921-1940 / Глав. арх. упр. при Совете Министров СССР; Ин-т марксизма-ленинизма при ЦК КПСС; Ин-т востоковедения АН СССР; Мин-во ин. дел 
СССР; Мин-во внеш. торг. СССР; Госкомитет Совета Министров СССР по внешним экон. связям; Ин-т экономики мировой соц. системы АН СССР; Глав. арх. упр. при Минве общ. безопасности МНР; Ин-т истории

\section{References}

Bayasakh Zh. New development of relations between Mongolia and its neighbors. Eurasia: statum et legem. 2017. No. 8. Pp. 6-12. (In Russ.)

Dmitriev S. V., Kuzmin S. L. Movement for the restoration of monarchy after the Xinhai Revolution (data from Russian archives). Restoration of the Qing monarchy by Zhang Xun. Vostok (Oriens). 2020. No. 4. Pp. 180195. (In Russ.)

Documents of the Soviet Foreign Policy. Vol. 4: March 19, 1921 - December 31, 1921. Ministry of Foreign Affairs of the USSR. Moscow: Gospolitizdat, 1960. 836 p. (In Russ.)

Dudin P. N. Precontractual essentials for the 'export of Revolution' in East Asia and regional political order in the zone of Soviet influence: positive experience and Socialist ideology in Mongolia. The year 1921. Oriental Studies. 2021. Vol. 14. No. 1. Pp. 8-23. (In Russ.)

Durdenevsky V. N., Ludshuveyt E. F. Constitutions of the East. Leningrad: Gosizdat, 1926. 180 p. (In Russ.)

Kuras L. V. 'Three lives' of Ataman G. M. Semyonov: love and betrayal (to the question of frontier). The Bulletin of Irkutsk State University. Series 'History'. 2014. Vol. 7. Pp. 94-113. (In Russ.)

Kuras L. V. Ataman Semenov's Great Mongolian State: the state that never existed. Eurasia: statum et legem. 2015. No. 1 (4). Pp. 84-96. (In Russ.)

Kuras L. V. Ataman Semenov's geopolitical ambitions: an attempt of creating a federative 'Great Mongolian State'. Humanitarian Vector. 2011. No. 4 (28). Pp. 255-262. (In Russ.)

Kuzmin S. L. Kuzmin S.L. 2015. The PanMongolian movement in the 1919-1920 and the Mongolian statehood. Eurasia: statum et legem. 2015. No. 1 (4). Pp. 97-107. (In Russ.)

Kuzmin S. L. Soviet-China relations, and the issue of Mongolia's status in the 1920s. In: Russia and Mongolia, Early to Mid-20 ${ }^{\text {th }}$ Century Conceptual Aspects of Russian-Mongolian Relations (Diplomacy, Economics, Science). партии при ЦК МНРП; Ин-т истории АН МНР; Мин-во ин. дел МНР. М.: Международные отношения; Улаанбаатар: Улсын хэвлэлийн газар, 1975. XVIII, 589 с.

Irkutsk: Baikal State University, 2015. Pp. 247255. (In Russ.)

Kuzmin S. L., Batsaykhan O., Nunami K., Tachibana M. Baron Ungern and Japan. Vostok (Oriens). 2009. No. 5. Pp. 115-133. (In Russ.)

Lenin V. I. Conversation with a Delegation of the Mongolian People's Republic: November 5, 1921. Ser.: Lenin V. I. Complete Works. Vol. 44. Moscow: Politizdat, 1970. 725 p. (In Russ.)

Mikhalev A. V. 'Progressors of the steppes': or Soviet specialists in Mongolia. Historical memory of one political project. In: Eastern Branches of the Russian Diaspora in Past and Present. Joint Monograph. Moscow: Institute of Oriental Studies (RAS), 2019. Pp. 15-34. (In Russ.)

Mikhalev A. V. Post-Jeltorussia: or Russian colonists in Socialist Mongolia. Bulletin of the Buryat Scientific Center of the Siberian Branch of the Russian Academy of Sciences. 2017. No. 4 (28). Pp. 80-88. (In Russ.)

Mikhalev A. V. The Mongolian Revolution of 1921 in Soviet and Russian Historiography. Cand. Sc. (history) thesis. Ulan-Ude, 2005. 154 p. (In Russ.)

Sabanin A. V., Broun V. O. (eds.) The USSR and Foreign Countries: Collected Existing Agreements, Treaties and Conventions. Vols. III: Documents That Came into Force before January 1, 1925. USSR People's Commissariat for Foreign Affairs. $3^{\text {rd }}$ ed., rev. and suppl. Moscow: People's Commissariat for Foreign Affairs, 1935. 484 p. (In Russ.)

Soviet-Mongolian Relations, 1921-1974 Documents and Materials. In 2 vols. Vol. 1: 1921-1940. Chief Archival Department (Council of Ministers of the Soviet Union), etc. Moscow: Mezhdunarodnye Otnosheniya; Ulaanbaatar: People's Publ. House, 1975. XVIII, 589 p. (In Russ. and Mong.)

Tisminets A. S. (comp.) Soviet Foreign Policy. Collected Documents. Vol. III: 1925-1934. Moscow: Supreme Party School (VKP(b) Central Committee), 1945. 800 p. (In Russ.) 